\title{
Pseudomonas synxantha 2-79 Transformed with Pyrrolnitrin Biosynthesis Genes Has Improved Biocontrol Activity Against Soilborne Pathogens of Wheat and Canola
}

\author{
Jibin Zhang, 1,3,† Dmitri V. Mavrodi,2,3 Mingming Yang,,3,4 Linda S. Thomashow,5 Olga V. Mavrodi,2,3 Jason Kelton,5 and \\ David M. Weller ${ }^{5, \dagger}$ \\ ${ }^{1}$ State Key Laboratory of Agricultural Microbiology, Huazhong Agricultural University, Wuhan, Hubei, P.R. China \\ ${ }^{2}$ School of Biological, Environmental, and Earth Sciences, The University of Southern Mississippi, Hattiesburg, MS 39406, U.S.A. \\ ${ }^{3}$ Department of Plant Pathology, Washington State University, Pullman 99164-6430, U.S.A. \\ ${ }^{4}$ Department of Agronomy, Northwest A\&F University, Yangling, P.R. China \\ ${ }^{5}$ U.S. Department of Agriculture-Agriculture Research Service, Wheat Health, Genetics and Quality Research Unit, Pullman, WA 99164- \\ 6430, U.S.A. \\ Accepted for publication 28 January 2020.
}

\begin{abstract}
A four-gene operon (prnABCD) from Pseudomonas protegens Pf-5 encoding the biosynthesis of the antibiotic pyrronitrin was introduced into $P$. synxantha (formerly $P$. fluorescens) $2-79$, an aggressive root colonizer of both dryland and irrigated wheat roots that naturally produces the antibiotic phenazine-1-carboxylic acid and suppresses both take-all and Rhizoctonia root rot of wheat. Recombinant strains ZHW15 and ZHW25 produced both antibiotics and maintained

AG-2-1, Gaeumannomyces graminis var. tritici, Sclerotinia sclerotiorum, Fusarium culmorum, and $F$. pseudograminearum significantly more than did strain 2-79. Both the wild-type and recombinant strains were equally inhibitory of Pythium ultimum. When applied as a seed treatment, the recombinant strains suppressed take-all, Rhizoctonia root rot of wheat, and Rhizoctonia root and stem rot of canola significantly better than did wild-type strain 2-79.
\end{abstract} population sizes in the rhizosphere of wheat that were comparable to those of strain 2-79. The recombinant strains inhibited in vitro the wheat pathogens Rhizoctonia solani anastomosis group 8 (AG-8) and
Keywords: antibiotics, biological control, Gaeumannomyces, phenazine1-carboxylic acid, pyrrolnitrin, Rhizoctonia, Sclerotinia
Wheat produced in the Pacific Northwest (PNW) of the United States is damaged by a wide variety of soilborne diseases including take-all, caused by Gaeumannomyces graminis var. tritici (Cook 2003), Rhizoctonia root rot, caused by $R$. solani anastomosis group 8 (AG-8) and R. oryzae (Okubara et al. 2014; Paulitz et al. 2002, 2010; Schillinger and Paulitz 2006), Fusarium crown rot, caused by $F$. pseudograminearum and F. culmorum (Smiley et al. 2005), and Pythium root rot, caused by a complex of Pythium spp. (Schroeder et al. 2006). Take-all is considered the most important root disease of wheat worldwide (Cook 2003) and is especially serious in China (Yang et al. 2011), the world's largest wheat producer. Rhizoctonia root rot has been a devastating disease in Australian cereal production for decades (MacNish and Neate 1996) and in the mid-1980s it emerged in PNW dryland cereal production (Weller et al. 1986). Now it is the most important disease of direct-seeded (no-till) wheat and barley (Paulitz 2006; Paulitz et al. 2002, 2010;

†Corresponding authors: D. M. Weller; david.weller@usda.gov, and

J. Zhang; zhangjb@mail.hzau.edu.cn

Funding: J. Zhang was supported by a grant from the China Scholarship Council.

U.S. Department of Agriculture (USDA) is an equal opportunity provider and employer. Mention of trade names or commercial products in this publication is solely for the purpose of providing specific information and does not imply recommendation or endorsement by the USDA.

*The $\boldsymbol{e}$-Xtra logo stands for "electronic extra" and indicates that two supplementary figures are published online.

The author(s) declare no conflict of interest.

This article is in the public domain and not copyrightable. It may be freely reprinted with customary crediting of the source. The American Phytopathological Society, 2020.
Schillinger and Paulitz 2006; Schroeder and Paulitz 2008) and remains the major barrier to the wider adoption of no-till and reduced tillage by growers in the PNW. Both Fusarium crown root and Pythium root rot are chronic problems in PNW wheat, and the former is favored by drought stress (Smiley et al. 2005) and the latter is favored by irrigation or high rainfall (Schroeder et al. 2006). These diseases often occur as a complex in the same field and management practices that control one of the diseases can exacerbate the other (Schroeder and Paulitz 2006).

Canola (oilseed rape) is a rotation crop that is increasingly popular in PNW cereal-based production systems because of greater demand for biodiesel and high-quality meal for animal production. For example, the State of Washington has mandated a target of 5\% biodiesel and $10 \%$ ethanol in the state's fuel supply. China continues to be the world's largest producer of oilseed rape. As in cereals, Rhizoctonia spp. cause severe damage to canola grown in the PNW, Canada, Europe, Australia, and China (KleinGebbinck and Woods 2002). Symptoms include pre- and postemergence damping-off, seedling root rot, and basal stem rot or foot rot of adult plants. Canola is damaged by several different anastomosis groups of $R$. solani (Huber and Christmas 1992; Kaminski and Verma 1985; Kataria and Verma 1992; Paulitz et al. 2006) but AG-2-1 is considered the most virulent (Fernando et al. 2007; Huber and Christmas 1992; Jaaffar et al. 2016; Kaminski and Verma 1985; Kataria and Verma 1992; Khangura et al. 1999). Sclerotinia stem rot, caused by Sclerotinia sclerotiorum, remains a serious and constant threat to canola and rapeseed production worldwide (Attanayake et al. 2013; del Río et al. 2007) and the major yield-limiting factor for the approximately 4.7 million ha of rapeseed produced annually in China, where it causes annual yield losses of 5 to $30 \%$ and up to $70 \%$, as well as a decrease in oil content from 1 to $5 \%$ (Fu 1995). 
The diseases described above share some common qualities: they are caused by ubiquitous necrotrophic soilborne pathogens, the host crops lack genetic resistance, and chemical treatments are only moderately effective or effective only during the seedling phase of the diseases (del Río et al. 2007; Okubara et al. 2014). In fact, plants generally lack resistance to many of the most common soilborne pathogens, and as a result, they rely on microbial-based mechanisms (biological control) as the first line of defense against attack by these pathogens. Microbial-based defenses, whether resulting from introduced or indigenous microorganisms, are modulated by the plant through rhizodeposition, which stimulates, enriches, and supports colonization and metabolite production by antagonistic microorganisms (Weller 2007). Disease suppressive soils provide some of the best examples of indigenous microorganisms protecting plant roots against soilborne pathogens (Schlatter et al. 2018; Weller et al. 2002), and instances of natural pathogen suppression have been rich sources of microorganisms for development into biological control agents (BCAs) (Schlatter et al. 2018).

Thousands of putative BCAs have been isolated and tested on hundreds of diseases with isolates of Trichoderma, Bacillus, and Pseudomonas, the organisms of choice for studies of biocontrol mechanisms and development into commercial BCAs (Weller and Thomashow 2015). Among the pseudomonads, some of the most effective strains are those that produce antibiotics, including phenazines, 2,4-diacetylphloroglucinol, pyrrolnitrin (Prn), and pyoluteorin. These compounds have been definitively shown to be linked to disease suppression (Haas and Défago 2005; Weller 2007).

Dozens of BCAs have been developed worldwide for commercial use in agriculture and their effectiveness continues to improve. However, BCAs are still thought to be less effective and inconsistent in performance, and to have too narrow of a spectrum of activity compared with synthetic chemical pesticides. In general, it is now thought that BCAs for soilborne pathogens are most effective when included in a broader disease management program that includes chemical pesticides. Genetic engineering offers an approach to enhance the consistency of performance, spectrum of activity, and the rhizosphere competence of BCAs, but research in this area has slowed over the last decade. Over the last 35 years, all mechanisms of biocontrol (competition/preemptive exclusion, parasitism/predation, induction of systemic resistance, and antibiosis/toxin production) have been targeted for improvement by genetic engineering (Dekkers et al. 2000; Dunne et al. 2000; Fenton et al. 1992; Maurhofer et al. 1998; Raaijmakers et al. 1995; Voisard et al. 1989; Weller and Thomashow 2015), but most common has been the introduction of antibiotic biosynthesis genes into a nonproducing strain or alteration of gene regulation of existing antibiotics (Bankhead et al. 2016; Delany et al. 2001; Hill et al. 1994; Huang et al. 2004; Leclère et al. 2005; Timms-Wilson et al. 2000; Weller and Thomashow 2015).

The aim of this study was to construct a recombinant biocontrol agent with enhanced activity against a broad spectrum of soilborne pathogens that commonly occur in cereal-based cropping systems in the PNW and China. We selected the well-described biocontrol strain $P$. synxantha (P. fluorescens) 2-79 because it produces phenazine-1-carboxylic acid (PCA) and its effectiveness against take-all disease of wheat is well documented (Thomashow and Weller 1988; Weller and Cook 1983). Strain 2-79 is part of a group of PCA-producing Pseudomonas species (P. aridus, P. cerealis, $P$. orientalis, and $P$. synxantha) in the $P$. fluorescens complex that suppress Rhizoctonia root rot (Jaaffar et al. 2017) and are highly adapted to colonizing the rhizosphere of wheat and barley crops that receive less than $381 \mathrm{~mm}$ (15 inches) of annual precipitation (Parejko et al. 2013). PCA can accumulate on dryland cereals to a level of greater than $1 \mu \mathrm{g} \mathrm{g}^{-1}$ of root (Mavrodi et al. 2012, 2018). Here we report on recombinant biocontrol Pseudomonas strains constructed by stably introducing the locus for the biosynthesis of Prn from $P$. protegens (formerly $P$. fluorescens) Pf-5 (Loper et al. 2012; Paulsen et al. 2005) into the chromosome of $P$. synxantha strain 2-79, which naturally produces PCA. The recombinant stains were significantly better than the wild-type strain 2-79 at suppressing take-all and Rhizoctonia root rot of wheat and Rhizoctonia root rot and damping-off of canola.

\section{MATERIALS AND METHODS}

Bacterial strains and pathogens. All bacterial strains used in this study and their relevant genotypes are listed in Table 1. Rhizoctonia solani AG-8 isolate C1 (Huang et al. 2004), R. solani AG-2-1 isolate T5S1-RS10 (Jaaffar et al. 2016), Gaeumannomyces graminis var. tritici isolate LD5 (Kwak et al. 2009), Sclerotinia sclerotiorum (WM-A1) (Xu et al. 2015), Pythium ultimum isolate T1R3, Fusarium culmorum isolate Fc70110023, and F. pseudograminearum isolate Fp2 (Poole, 2010) were used in laboratory and/or greenhouse assays.

Construction of recombinant Prn-producing derivatives of $\boldsymbol{P}$. synxantha strain 2-79. Standard methods were used for DNA isolation, restriction enzyme digestion, agarose gel electrophoresis, ligation, and transformation. P. protegens strain Pf-5 (Loper et al. 2012) served as the source of the Prn biosynthesis operon. To construct the prn gene cassette, a 3,951-bp fragment containing the $p r n A B C$ genes of Pf- 5 was amplified with primers prn1 (5'-TTT TTC ATA TGA ACA AGC CAA TCA AG-3') and prn2 (5'-GAG AAC GCC GTG TAG CAG CAG-3') using KOD DNA polymerase (Novagen). The fragment was digested with $\mathrm{NdeI}$ and HindIII and subcloned into the gene expression vector pCYB2 (New England Biolabs). Next, a 1,850-bp fragment containing the distal end of $p r n C$ and the entire $p r n D$ gene was amplified with primers prn3 (5' -ACC GCT ACT GCC TGA TGC TG-3') and prnR (5'-AGC TGG GTT CTA CCT GCT CAC TCG CGA CAC GGT-3') and digested with HindIII. The fragment was cloned into pCYB2prnABC that had been treated with BamHI, the Klenow fragment of DNA polymerase I and HindIII. This produced a pCYB2-based plasmid containing the complete prn locus under the control of the Ptac promoter. The 5.8-kb fragment with the Ptac promoter and prn genes was then reamplified using nested PCR with primer $\operatorname{prnF}\left(5^{\prime}\right.$ CTG TTG ACA ATT AAT CAT CGG CTC GTATAATG-3'), prnR and prn2F-2R, and cloned using BP Clonase II (Invitrogen) into the Gateway entry plasmid vector pMK2010 (House et al. 2004). The construct was single-pass sequenced to confirm the absence of mutations. The Ptac-prnABCD fusion was then swapped into $\mathrm{pBK}$ mini-Tn7 $\Omega \mathrm{Gm}-c c d B$ using LR Clonase II (Invitrogen). This plasmid was transformed into $E$. coli $\mathrm{DH} 5 \alpha$ and mobilized into P. synxantha 2-79 $\left(\mathrm{Phz}^{+}, \mathrm{Rif}^{\mathrm{r}}\right)$ by using a four-parental filter mating technique. Matings were carried out with the donor strain $E$. coli $\mathrm{DH} 5 \alpha$ (pBKTn7Gm-PRN) $\left(\mathrm{Gm}^{\mathrm{r}}, \mathrm{Amp}^{\mathrm{r}}\right)$, the recipient strain P. synxantha 2-79 $\left(\mathrm{Rif}^{\mathrm{r}}\right)$, and the helper strains E. coli SM10 $\lambda$ pir (pUX-BF13) $\left(\mathrm{Amp}^{\mathrm{r}}\right)$ (Koch et al. 2001) and E. coli HB101(pRK600) (Cmr) (de Lorenzo and Timmis 1994). Recombinant derivatives of 2-79, modified with a single copy of the

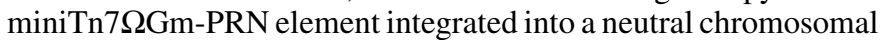
site, were selected on King's medium B (KMB) supplemented with rifampicin at $100 \mu \mathrm{g} \mathrm{ml}^{-1}$ and gentamycin at $100 \mu \mathrm{g} \mathrm{ml}^{-1}$. The presence of the Prn and PCA genes was confirmed by PCR with Prn (prn1 (5'-TTT TTC ATA TGA ACA AGC CAA TCA AG-3') and prnseq2 (5' -CAC GCT GCC GAA CAA ATG-3') and PCA-specific primers (Mavrodi et al. 2018). Growth kinetics in vitro of wild-type 2-79 and its Prn-producing recombinant derivatives were compared in $1 / 3 \times \mathrm{KMB}$ broth and M9 broth $\left(\mathrm{OD}_{600 \mathrm{~nm}}\right)$ for $48 \mathrm{~h}$ with a TECAN Safire microplate reader (Männedorf, Switzerland).

Fungal inhibition in vitro. Growth inhibition of six soilborne fungal pathogens by $P$. synxantha 2-79, 2-79Phz-, and recombinant strains ZHW15 and ZHW25 was tested on potato dextrose agar (PDA) (Yang et al. 2011). We also included another strain of $P$. synxantha and strains of $P$. aridus, $P$. cerealis, and $P$. orientalis because they are genetically related to 2-79, are abundant in the lowprecipitation zone of the Columbia Plateau, and only produce PCA. 
In addition, $P$. chlororaphis 30-84 was included because it has been widely tested against both take-all and Rhizoctonia root rot and it naturally produces three phenazine antibiotics (phenazine-1carboxylic acid, 2-hydroxy-phenazine-1-carboxylic acid, and 2hydroxy-phenazine) and Prn. An aliquot of $5 \mu$ from an overnight culture of bacteria grown in $\mathrm{KMB}$ broth to an $\mathrm{OD}_{600}$ of 0.1 was spotted $1 \mathrm{~cm}$ from the edge of the plate and a plug $(0.5 \mathrm{~cm}$ diameter $)$ cut from the leading edge of a fungal colony grown on $1 / 5 \times$ PDA, was placed at the center of the plate. The negative control consisted of just the fungal plug placed on the PDA plate without any bacteria. The plates were incubated in the dark at room temperature $\left(23^{\circ} \mathrm{C}\right)$. When the growth of the fungi in the negative controls reached near the edge of the plate without bacteria (up to 5 days), the radial growth of the fungus was measured. Each treatment was replicated three times and each plate served as a replicate.

Seed treatment. Spring wheat (cultivar Penawawa) and canola seeds were coated with bacteria as previously described (Pierson and Weller 1994; Yang et al. 2011). Bacterial inoculum was grown on $\mathrm{KMB}$ agar plates for $48 \mathrm{~h}$ at $27^{\circ} \mathrm{C}$. Cells were scraped from the plates, suspended in sterile water, washed twice by centrifugation for $3 \mathrm{~min}(14,000 \mathrm{rpm})$, and diluted to give the appropriate bacterial concentration. Methyl cellulose $(2.0 \%)$ was added to the bacterial suspension and seeds were coated with the suspension, mixed, and air-dried overnight in a laminar flow hood. For biocontrol and colonization studies, seeds were coated with a dose of approximately $10^{7}$ and $10^{5} \mathrm{CFU}$ seed $^{-1}$, respectively.

Disease suppression assays. Tube assays were used to test the biocontrol activity of the parental and recombinant strains against take-all and Rhizoctonia root rot of wheat and Rhizoctonia root rot and damping-off of canola essentially as previously described (Yang et al. 2011, 2014). Pathogen inoculum was prepared by

TABLE 1. Bacteria and plasmids used in this study

\begin{tabular}{|c|c|c|}
\hline $\begin{array}{l}\text { Organism, strain, } \\
\text { or plasmid }\end{array}$ & Genotype/characteristics & Source/reference \\
\hline \multicolumn{3}{|l|}{$\begin{array}{l}\text { Pseudomonas } \\
\text { synxantha }\end{array}$} \\
\hline $2-79$ & $\mathrm{Phz}^{+}$Rif $^{\mathrm{r}}$ & $\begin{array}{l}\text { Thomashow and } \\
\text { Weller (1988) }\end{array}$ \\
\hline ZHW15 & $\mathrm{Phz}^{+} \mathrm{Rif}^{\mathrm{r}} \mathrm{Prn}^{+}$ & This study \\
\hline ZHW15 & $\mathrm{Phz}^{+} \mathrm{Rif}^{\mathrm{r}} \mathrm{Prn}^{+}$ & This study \\
\hline $2-79 \mathrm{Phz}^{-}$ & $\mathrm{Phz}^{-} \mathrm{Rif}^{\mathrm{r}}$ & Khan et al. (2005) \\
\hline R6-28-08 & $\mathrm{Phz}^{+} \mathrm{Rif}^{\mathrm{r}}$ & Parejko et al. (2013) \\
\hline \multicolumn{3}{|l|}{ P. cerealis } \\
\hline $4(1): 2-10$ & $\mathrm{Phz}^{+} \mathrm{Rif}^{\mathrm{r}}$ & Parejko et al. (2013) \\
\hline L1-45-08 & $\mathrm{Phz}^{+} \mathrm{Rif}^{\mathrm{r}}$ & Parejko et al. (2013) \\
\hline \multicolumn{3}{|l|}{ P. aridus } \\
\hline R1-43-08 & $\mathrm{Phz}^{+} \mathrm{Rif}^{\mathrm{r}}$ & Parejko et al. (2013) \\
\hline S3-6:7-09 & $\mathrm{Phz}^{+} \mathrm{Rif}^{\mathrm{r}}$ & Parejko et al. (2013) \\
\hline \multicolumn{3}{|l|}{ P. orientalis } \\
\hline R2-66-08W & $\mathrm{Phz}^{+} \mathrm{Rif}^{\mathrm{r}}$ & Parejko et al. (2013) \\
\hline L1-03-08 & $\mathrm{Phz}^{+} \mathrm{Rif}^{\mathrm{r}}$ & Parejko et al. (2013) \\
\hline \multicolumn{3}{|l|}{ P. chlororaphis } \\
\hline $30-84$ & $\mathrm{Phz}^{+} \mathrm{Rif}^{\mathrm{r}}$ & $\begin{array}{l}\text { Pierson and } \\
\text { Thomashow (1992) }\end{array}$ \\
\hline $30-84 \mathrm{phz}^{-}$ & $\mathrm{Phz}^{-} \mathrm{Rif}^{\mathrm{r}}$ & $\begin{array}{l}\text { Pierson and } \\
\text { Thomashow (1992) }\end{array}$ \\
\hline \multicolumn{3}{|l|}{ P. protegens } \\
\hline Pf-5 & $\mathrm{Prn}^{+} \mathrm{Phl}^{+} \mathrm{Plt}^{+}$ & Loper et al. (2012) \\
\hline \multicolumn{3}{|l|}{ Escherichia coli } \\
\hline DH5 $\alpha$ & $\begin{array}{l}\mathrm{F}^{-} \text {endA1 hsdR17 supE44 } \\
\text { thi-1 gyrA96 relA1 } \\
\text { AargF-lacZYA U169 } \\
\text { d80dlacZAM15 } \lambda-\end{array}$ & Laboratory collection \\
\hline SM10 $\lambda$ pir & $\begin{array}{l}\text { thi thr leu tonB lacY supE } \\
\text { recA RP4-2(Tc:: Mu, } \\
\text { Km::Tn7) } \mathrm{Km}^{\mathrm{r}} \lambda \text { pir }\end{array}$ & Laboratory collection \\
\hline HB101 & 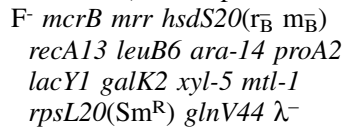 & Laboratory collection \\
\hline
\end{tabular}

growing each fungus on autoclaved whole oat grains as previously described (Yang et al. 2011, 2014). The colonized grains were stored at $4^{\circ} \mathrm{C}$ until used. Plastic tapered tubes $(2.5 \mathrm{~cm} \times 20 \mathrm{~cm})$ with holes at the bottom were plugged with cotton balls and then filled to a height of about $3 \mathrm{~cm}$ with fine sterile vermiculite, followed by $10 \mathrm{~g}$ of raw Quincy virgin soil (Shano sandy loam) (Yang et al. 2011, 2014), with or without inoculum of a pathogen. For biocontrol assays of take-all and Rhizoctonia root rot of wheat, the soil was amended with $0.7 \%$ (wt/wt) of freshly ground oat kernel inoculum (sieved to collect particle sizes of 0.25 to $0.50 \mathrm{~mm}$ ). For assays of root rot and damping-off of canola, the soil was amended with $0.1 \%$ inoculum of $R$. solani $\mathrm{AG}-2-1$. Each tube received $10 \mathrm{ml}$ of water amended with metalaxyl ( $0.6 \mathrm{~g}$ per 8 liters) to minimize infection by Pythium spp., which is indigenous in soils of the PNW. For take-all suppression assays, the tubes were seeded immediately, and for Rhizoctonia suppression assays the tubes were seeded after incubation at room temperature for $48 \mathrm{~h}$. Three wheat or six canola seeds were sown per tube and covered with about $5 \mathrm{ml}$ of sterile vermiculite. The tubes were arranged in a randomized complete block design and incubated in a growth chamber for three weeks (12-h photoperiod, $16^{\circ} \mathrm{C}$ ). After seedling emergence ( 3 to 4 days), each tube was watered three times weekly, and one of those times with $10 \mathrm{ml}$ of one-third-strength Hoagland's solution. Each treatment was replicated five times with five tubes per replicate. Rhizoctonia root rot and take-all in wheat were evaluated by measuring plant height and scoring disease severity on a scale of 0 to 8 . Disease caused by $R$. solani AG-2-1 on canola was evaluated by determining seedling emergence and postemergence damping-off and shoot length. All experiments were conducted two times with similar results.

Detached-leaf assays for biological control of $S$. sclerotiorum. Each detached canola leaf was sprayed with a 1-ml aliquot of a bacterial suspension adjusted to a dose of $10^{5} \mathrm{CFU} \mathrm{ml}{ }^{-1}$ and prepared as described above. A mycelial plug ( $0.5 \mathrm{~cm}$ diameter) of S. sclerotiorum WM-A1 grown as described above was placed in the center of the leaf $24 \mathrm{~h}$ later. The canola leaves were incubated in culture dishes on filter paper moistened with water and incubated at room temperature $\left(23^{\circ} \mathrm{C}\right)$ in the dark. The area of hyphal growth on each detached leaf was recorded at 4 and 6 days after inoculation of the pathogen. Each bacterial strain (treatment) had nine replicates consisting of a single leaf. The experiment was performed twice with similar results.

Hyphal growth on the canola leaf was measured in two directions (long and short axes of growth) and averaged. The area of hyphal growth radius was determined using the following formula: Area = $\pi$ (radius) $)^{2}$ (Hu et al. 2005). The percent inhibition of $S$. sclerotiorum by the bacterial treatments was calculated by the following formula:

Inhibition $(\%)=$

CK hyphal growth area $\left(\mathrm{cm}^{2}\right)$ - treatment hyphal growth area $\left(\mathrm{cm}^{2}\right)$ CK hyphal growth area $\left(\mathrm{cm}^{2}\right)$

Antibiotic identification. A lawn of bacteria was grown on Luria-Bertani agar amended with $2 \%$ glucose at $28^{\circ} \mathrm{C}$ for $66 \mathrm{~h}$. The agar was cut into small pieces and extracted with acetone and chloroform. The crude extracts and purified preparations were analyzed for Prn by thin-layer chromatography (TLC) with Silica Gel GHLF plates and chloroform-hexane (4:1, vol/vol). Extracts of the bacteria were compared with a pure sample of Prn. Visualization was performed by exposing the plates to air for $10 \mathrm{~min}$ and monitoring at $254 \mathrm{~nm}$.

Colonization of the wheat rhizosphere by strain 2-79 and the recombinants. The ability of strains $2-79$, ZHW15, and ZHW25 to colonize the rhizosphere of wheat was determined using a pot cycling experiment essentially as described by Bankhead et al. (2016). This assay tests the ability of bacteria not only to colonize the roots when introduced, but then to recolonize the roots from bacteria remaining in the soil or on old roots when the soil is 
replanted. Each bacterial treatment consisted of four pots, with each pot serving as a replicate. Quincy virgin soil (200 g) was added to square plastic pots $(8 \mathrm{~cm}$ high, $7.5 \mathrm{~cm}$ wide) and $50 \mathrm{ml}$ of water was added to each pot immediately prior to planting. Wheat seeds were treated with the bacterial strains essentially as described above to give a dose of $10^{5} \mathrm{CFU}$ seed ${ }^{-1}$. Twelve seeds (cultivar Penewawa) were sown in each pot and covered with $50 \mathrm{~g}$ of soil. Pots were incubated and watered as needed, and after 3 weeks six seedlings were selected at random from each replicate pot and shaken to remove the loosely adhering soil to enumerate bacterial populations. The soil and cut roots from the remaining plants were mixed, returned to the pots, sown to 12 nontreated seeds, and incubated as described above (cycle 2). The experiment continued for three cycles. Roots were excised from the seedlings at the base of the stem and bacteria were liberated from each root system separately by vortexing in $10 \mathrm{ml}$ of water in 50 -ml centrifuge tubes followed by sonication as previously described (Bankhead et al. 2016; Yang et al. 2011). Population sizes of the introduced strains on each root were determined by the PCR-based dilution-endpoint assay as described (Bankhead et al. 2016; Yang et al. 2011). Briefly, each root washing solution was serially diluted in a 96 -well plate $(100 \mu \mathrm{l}$ added into a well prefilled with $200 \mu \mathrm{l}$ of water) and then $50 \mu \mathrm{l}$ of each dilution was transferred to wells of a plate prefilled with $200 \mu \mathrm{l}$ of $1 / 3 \times \mathrm{KMB}$ broth supplemented with ampicillin, chloramphenicol, cycloheximide, and rifampicin (Bankhead et al. 2016; Yang et al. 2011). Growth in each well was determined after 3 days of incubation at room temperature by measuring $\mathrm{OD}_{600}$. Population size of each strain was based on the final dilution that contained growth and was positive for $p h z F$ by PCR using primers specific for the PCA biosynthesis locus (Bankhead et al. 2016; Yang et al. 2011).

Statistical analysis. All experiments were conducted at least twice with similar results. Biocontrol and root colonization experiments were arranged in a randomized complete block design and data were analyzed with STATISTIX 8.0 software (Analytical Software, St. Paul, MN). Population data were converted to $\log$ CFU $\mathrm{g}^{-1}$ of fresh root weight before analysis. Differences in population densities, root disease, or plant height among treatments were determined by standard analysis of variance, and mean comparisons among treatments were performed by using either the Fisher's protected least significant difference test $(P=0.05)$ or the KruskalWallis test $(P=0.05)$.

\section{RESULTS}

Selection and characterization in vitro of recombinant strains. Mating of $P$. fluorescens 2-79 with E. coli DH5 $\alpha$ $(\mathrm{pBKTn} 7 \mathrm{Gm}-\mathrm{PRN})\left(\mathrm{Gm}^{\mathrm{r}}, \mathrm{Amp}^{\mathrm{r}}\right)$ yielded 32 recombinant colonies, and the presence of the introduced Prn genes in them was confirmed by PCR using the Prn-specific primers prn1 and prnseq2 (Fig. 1). Nine of the 32 colonies were selected after growth on M9 agar containing kanamycin. These clones, designated ZHW2, ZHW6, ZHW11, ZHW14, ZHW15, ZHW18, ZHW19, ZHW23, and ZHW25, remained rifampicin- and gentamycin-resistant after several successive transfers on KMB agar and their colony size, morphology, and color were stable and similar to that of stain 2-79. The growth rate of the nine recombinant strains and 2-79 in $1 / 3 \times \mathrm{KMB}$ broth and $\mathrm{M} 9$

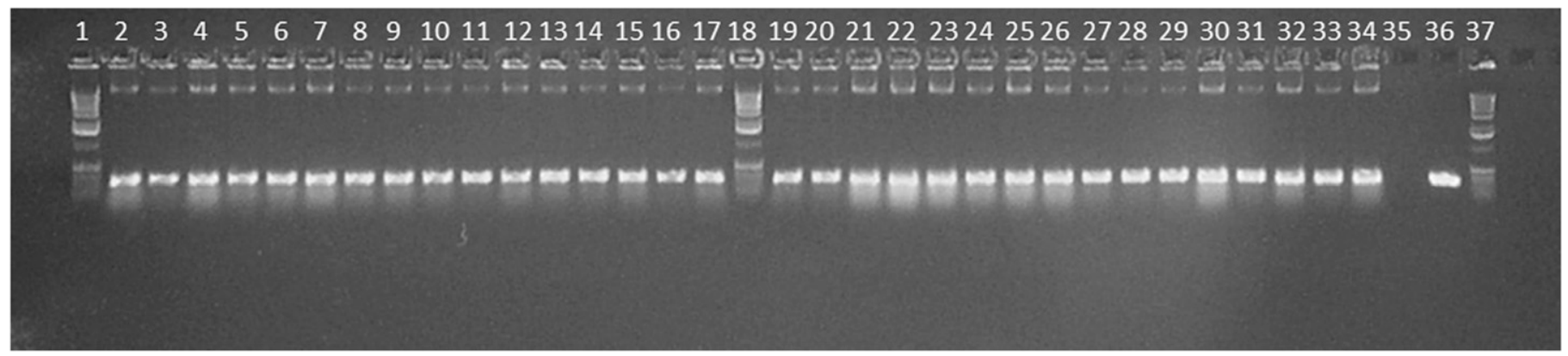

Fig. 1. DNA from 32 recombinant colonies of 2-79 (2 to 17 and 19 to 34) was confirmed to contain genes for the biosynthesis of pyrrolnitrin by PCR using the primers prn1 and prnseq2; negative control (35); and positive control (36).

TABLE 2. Inhibition in vitro of wheat root pathogens by $2-79$, recombinant derivatives and other phenazine producing-pseudomonads

\begin{tabular}{|c|c|c|c|c|c|c|}
\hline \multirow[b]{2}{*}{ Strain } & \multicolumn{6}{|c|}{ Radial growth $(\mathrm{mm})^{\mathrm{y}}$} \\
\hline & $\begin{array}{l}\text { Rhizoctonia } \\
\text { solani AG-8 }\end{array}$ & $\begin{array}{l}\text { Gaeumannomyces } \\
\text { graminis var. tritici }\end{array}$ & $\begin{array}{l}\text { Fusarium } \\
\text { culmorum }\end{array}$ & $\begin{array}{c}\text { Fusarium } \\
\text { pseudograminearum }\end{array}$ & $\begin{array}{c}\text { Sclerotinia } \\
\text { sclerotiorum }\end{array}$ & Pythium \\
\hline \multicolumn{7}{|l|}{ Pseudomonas synxantha } \\
\hline 2-79phz ${ }^{-}$ & $29.9 \mathrm{~A}^{\mathrm{z}}$ & $42.0 \mathrm{~A}$ & $38.5 \mathrm{~A}$ & $33.8 \mathrm{~A}$ & $28.3 \mathrm{~A}$ & $28.8 \mathrm{~A}$ \\
\hline P. chlororaphis $30-84 \mathrm{phz}^{-}$ & $26.3 \mathrm{~B}$ & $42.0 \mathrm{~A}$ & $36.5 \mathrm{~A}$ & $32.8 \mathrm{~A}$ & $26.7 \mathrm{AB}$ & $28.5 \mathrm{~A}$ \\
\hline P. cerealis $4(1): 2-10$ & $22.0 \mathrm{C}$ & $20.5 \mathrm{~F}$ & $32.0 \mathrm{BC}$ & $27.2 \mathrm{CD}$ & $25.4 \mathrm{~B}$ & $24.3 \mathrm{BC}$ \\
\hline P. cerealis L1-45-08 & $21.0 \mathrm{D}$ & $20.7 \mathrm{EF}$ & $30.3 \mathrm{C}$ & $28.1 \mathrm{CD}$ & $19.9 \mathrm{D}$ & $25.5 \mathrm{~B}$ \\
\hline P. aridus R1-43-08 & $20.2 \mathrm{D}$ & $20.2 \mathrm{FG}$ & $24.3 \mathrm{E}$ & $26.8 \mathrm{D}$ & $23.0 \mathrm{C}$ & $23.2 \mathrm{CDE}$ \\
\hline P. synxantha $\mathrm{R} 6-28-08$ & $19.8 \mathrm{E}$ & $21.4 \mathrm{D}$ & $23.3 \mathrm{E}$ & $28.1 \mathrm{CD}$ & $20.5 \mathrm{D}$ & $22.4 \mathrm{DEF}$ \\
\hline P. aridus S3-6:7-09 & $19.7 \mathrm{E}$ & $23.5 \mathrm{~B}$ & $28.0 \mathrm{D}$ & $31.3 \mathrm{~B}$ & $20.5 \mathrm{D}$ & $21.5 \mathrm{EF}$ \\
\hline P. synxantha 2-79 & $19.4 \mathrm{EF}$ & $22.4 \mathrm{C}$ & $32.6 \mathrm{~B}$ & $28.3 \mathrm{C}$ & $17.3 \mathrm{EF}$ & $23.8 \mathrm{BCD}$ \\
\hline P. orientalis R2-66-08W & $18.5 \mathrm{FG}$ & $19.5 \mathrm{G}$ & $31.5 \mathrm{BC}$ & $28.3 \mathrm{C}$ & $14.2 \mathrm{G}$ & $21.3 \mathrm{~F}$ \\
\hline P. chlororaphis $30-84$ & $18.2 \mathrm{G}$ & $16.7 \mathrm{I}$ & $18.2 \mathrm{~F}$ & $24.8 \mathrm{E}$ & $16.5 \mathrm{~F}$ & $18.3 \mathrm{G}$ \\
\hline P. orientalis L1-03-08 & $16.6 \mathrm{H}$ & $18.6 \mathrm{H}$ & $31.3 \mathrm{BC}$ & $27.1 \mathrm{CD}$ & $18.9 \mathrm{DE}$ & $21.3 \mathrm{~F}$ \\
\hline P. synxantha $\mathrm{ZHW} 15$ & $10.7 \mathrm{I}$ & $21.3 \mathrm{DE}$ & $15.8 \mathrm{G}$ & $15.5 \mathrm{~F}$ & $6.8 \mathrm{H}$ & $24.9 \mathrm{BC}$ \\
\hline P. synxantha ZHW25 & $10.4 \mathrm{I}$ & $21.3 \mathrm{DE}$ & $15.5 \mathrm{G}$ & $15.7 \mathrm{~F}$ & $6.7 \mathrm{H}$ & $24.5 \mathrm{BC}$ \\
\hline
\end{tabular}

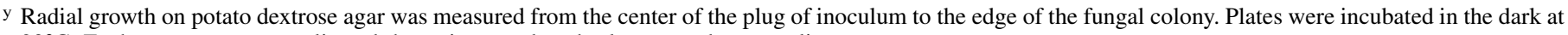
$23^{\circ} \mathrm{C}$. Each treatment was replicated three times and each plate served as a replicate.

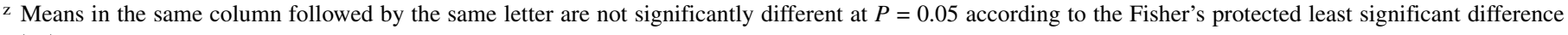
test. 
broth was similar (data not shown). All nine colonies produced Prn based on detection of the antibiotic by TLC (data not shown).

For further studies, we selected strains ZHW15 and ZHW25. The recombinant strains inhibited the growth of $R$. solani AG-8 significantly more than strain 2-79 and the other phenazine-producing wild-type strains of $P$. synxantha, $P$. orientalis, $P$. aridus, $P$. cerealis, and $P$. chlororaphis (Table 2). The recombinant strains also showed significantly greater inhibition of $R$. solani AG-2-1 (data not shown), $S$. sclerotiorum, F. culmorum, and F. pseudograminearum compared with strain 2-79 and the other strains tested. An example of this enhanced level of inhibition by the recombinants is shown in Figure 2. The recombinant strains ZHW15 and ZHW25 inhibited the growth of $G$. graminis var. tritici significantly more than strain 2-79, but not more than the other wild-type strains. Strain 30-84 was the most inhibitory strain against $G$. graminis var. tritici. The recombinants were not more inhibitory of Pythium ultimum compared with the other wild-type strains. Strains 2-79phz- and

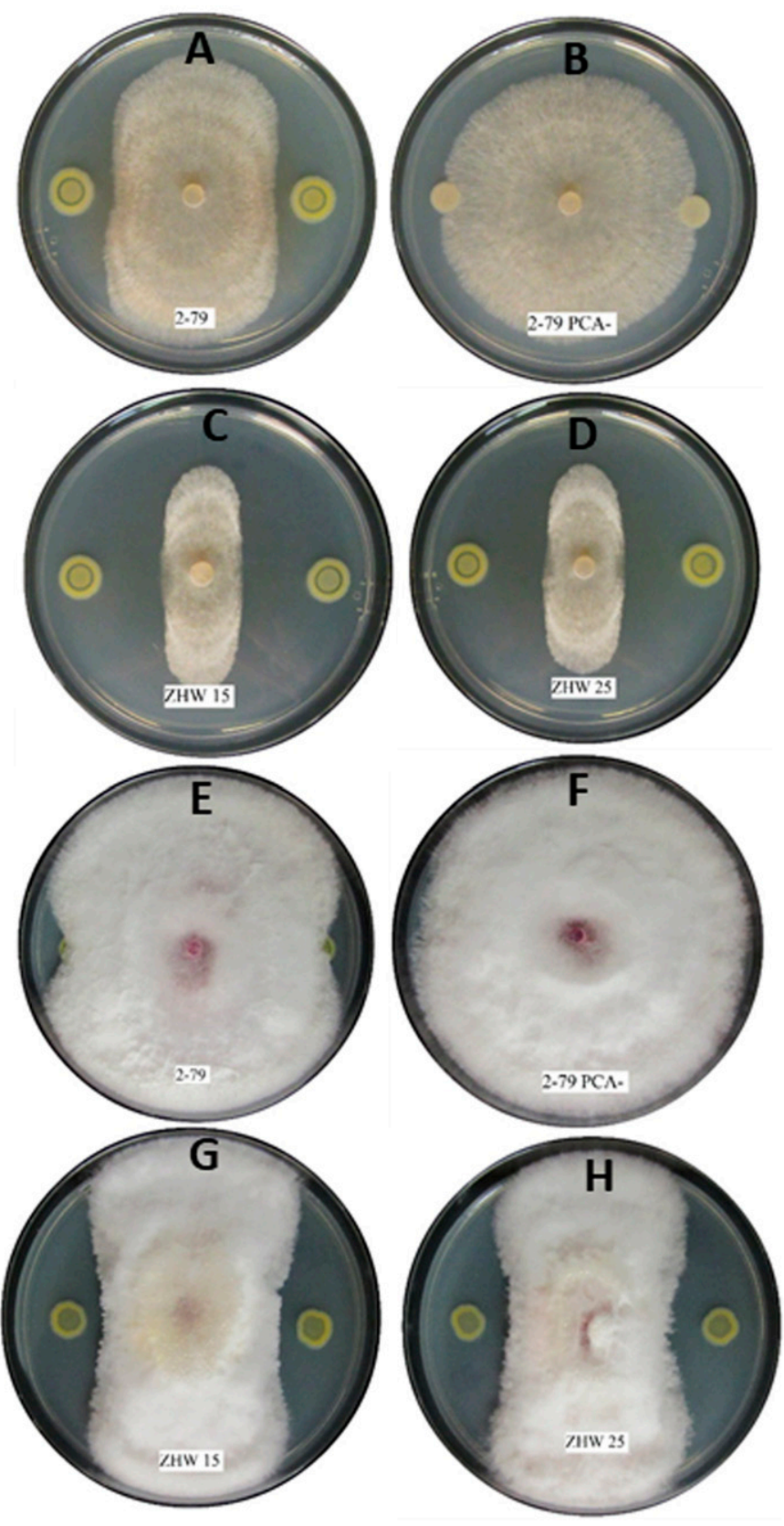

Fig. 2. Examples of inhibition of Rhizoctonia solani anastomosis group 8 (AG8) by A, 2-79, B, 2-79 PCA-, C, ZHW15, and D, ZHW25; and inhibition of Fusarium pseudograminearum by E, 2-79, F, 2-79 PCA-, G, ZHW15, and H, ZHW25 on potato dextrose agar. 30-84phz-, which lacked the ability to produce phenazines, caused little or no inhibition of any of the pathogens and also served as controls (Table 2). TLC results showed that cultures of the two recombinant strains ZHW15 and ZHW25 produced both Prn and PCA in vitro, and the wild-type 2-79 produced only PCA but not Prn (data not shown).

Suppression of root and foliar diseases by strain 2-79 and the recombinants. Strain 2-79 and the recombinant strains ZHW15 and ZHW25, applied at a dose of $10^{7} \mathrm{CFU}$ seed $^{-1}$, provided significantly greater $(P=0.05)$ suppression of Rhizoctonia root rot of wheat based on root disease ratings compared with the two controls, nontreated seeds and $2.0 \%$ methyl cellulose-treated seeds. However, the recombinants provided significantly greater control of Rhizoctonia root rot than did strain 2-79 (Table 3, Supplementary Fig. S1). The recombinants also provided significantly greater $(P=$ $0.05)$ suppression of take-all of wheat based on root disease ratings (Supplementary Fig. S2) and Rhizoctonia root rot of canola based on plant height measurements compared with strain 2-79 (Table 3). Strain 2-79 and the recombinants significantly $(P=0.05)$ suppressed the growth of $S$. sclerotiorum on canola leaves, but there were no differences in effectiveness among 2-79, ZHW15, and ZHW25. S. sclerotiorum hyphal growth for the control, 2-79, ZHW15, and ZHW25 were $3.9,1.3,1.3$, and $0.6 \mathrm{~cm}^{2}$, respectively.

Colonization in the wheat rhizosphere. Strains 2-79, ZHW15, and ZHW25 applied at $10^{5}$ CFU seed ${ }^{-1}$ increased their population sizes up to 1,000 -fold on the seed during the first cycle (data not shown). Over the three cycles of wheat, population sizes of the bacteria ranged from $\log 6.07$ to $7.44 \mathrm{CFU} \mathrm{g}{ }^{-1}$ of fresh root weight, and generally were greatest for 2-79, ZHW15, and ZHW25 in cycle 1 and lowest in cycle 3. Populations of the three strains did not differ significantly in any cycle, indicating that the recombinants did not lose rhizosphere competence (Table 4).

\section{DISCUSSION}

Plants lack resistance to most necrotrophic soilborne pathogens, and two or more pathogens typically infect a single root system. For example, R. solani, G. graminis var. tritici, Pythium spp., and F. pseudograminearum or F. culmorum usually occur in the same field and may simultaneously infect wheat and barley. In canola (oilseed rape), $R$. solani and $S$. sclerotiorum commonly occur on the same crop. Chemical controls for soilborne pathogens are very limited and usually are effective only during the seedling phase of the disease (Cook et al. 2002). The use of biocontrol agents to control soilborne pathogens is increasing, but they generally have a very narrow spectrum of activity and therefore are thought to be most effective when applied along with chemical fungicides. The use of genetically engineered biocontrol agents remains a totally untapped resource for expanding the spectrum and effectiveness of biocontrol agents against soilborne pathogens in commercial agriculture, largely because of public concerns about this type of technology. Our goal was to construct a recombinant Pseudomonas strain with enhanced biocontrol activity from components that are widely distributed in agroecosystems. Thus, such a strain may be perceived as less of an environmental threat when released.

For our study, we selected $P$. synxantha $2-79$ as the recipient strain because it is a very well-studied pseudomonad that aggressively colonizes wheat and barley roots under both dryland and irrigated condition (Weller 1983, 1984; Yang et al. 2011) and controls takeall of wheat in the field (Weller and Cook 1983). Strain 2-79, isolated in 1979, is part of a complex of PCA-producing Pseudomonas species including $P$. synxantha, $P$. orientalis, $P$. cerealis, and $P$. aridus, which are ubiquitous and abundant in the rhizospheres of all wheat and barley grown in the low-precipitation zone of the Columbia Plateau of the PNW of the United States (Mavrodi et al. 2012, Parejko et al. 2012, 2013). PCA-producing pseudomonads similar to strain 2-79 are also abundant on the 
roots of Chinese wheat (Yang et al. 2011). In the PNW lowprecipitation agroecosystem, PCA accumulates on roots of wheat to concentrations of up to $1.5 \mu \mathrm{g} \mathrm{g}^{-1}$ of root (Mavrodi et al. 2012, 2018 ) and provides a level of natural suppression of $R$. solani, F. pseudograminearum, and F. culmorum (D. M. Weller and L. S. Thomashow, unpublished data). P. protegens Pf-5 was selected as the donor of the Prn biosynthesis operon because it is the most thoroughly characterized of all biocontrol agents (Loper et al. 2012), suppresses a very wide variety of soilborne fungal pathogens, parasitic nematodes, and some insects (Péchy-Tarr et al. 2008), and similar strains are common in agroecosystems worldwide (Haas and Défago 2005; Jousset et al. 2014; Ramette et al. 2011; Wang et al. 2015). Strain Pf-5 was the first biocontrol agent to be sequenced (Paulsen et al. 2005) and this strain devotes about $6.0 \%$ of its genome to biosynthesis genes for antibiotics and metabolites that could be involved in pathogen or insect inhibition (Loper et al. 2007; Paulsen et al. 2005). The genome of strain Pf-5 is very close to that of the equally well-described $P$. protegens strain CHA0 (Jousset et al. 2014).

The production of both PCA and Prn in a single strain is an ideal combination of antibiotics for biocontrol. PCA is abundantly produced by 2-79 in vitro and in the rhizosphere and has very broadspectrum activity against bacteria and fungi. It is the primary mechanism by which 2-79 suppresses G. graminis var. tritici (Thomashow and Weller 1988; Thomashow et al. 1990). In addition, PCA is a rhizosphere competence factor (Mazzola et al. 1992), promotes biofilm formation in 2-79 (LeTourneau et al. 2018), which stabilizes soil particles, mobilizes iron in the rhizosphere (LeTourneau et al. 2019), and induces resistance against foliar pathogens (Weller et al. 2015). In China, PCA is produced as Shenqinmycin from a genetically engineered strain of P. aeruginosa for use as a foliar fungicide (Zhao et al. 2018); thus, this antibiotic already is abundant in agroecosystems, being either naturally produced on roots or sprayed in the field. PCA's main drawback is a short half-life of 3 to 4 days in the rhizosphere (LeTourneau et al. 2018; Mavrodi et al. 2012); however, field studies have demonstrated that the 2-79 and similar pseudomonads continually produces PCA in the rhizosphere throughout the growing season, even as the soil water potential declines (LeTourneau et al. 2018; Mavrodi et al. 2018; Yang et al. 2011).

Prn (3-chloro-4-(2'-nitro-3' -chlorophenyl)-pyrrole) is a secondary metabolite derived from tryptophan and was first isolated from P. pyrrocinia (Arima et al. 1964). It also has broad-spectrum antifungal and antibacterial activity (Hammer et al. 1999) but is especially active against Rhizoctonia spp. (Arima et al. 1964; Chernin et al. 1996; El-Banna and Winkelmann 1988; Hill et al. 1994; Howell and Stipanovic 1979). Hill et al. (1994) showed that mutants of $P$. fluorescens strain BL915 that did not produce Prn could not suppress damping-off of cotton caused by $R$. solani.
Rhizoctonia spp. are unquestionably one of the top 10 soilborne pathogens on all crops worldwide and always a target that needs to be controlled. Prn is also effective against a variety of other diseases such as postharvest disease caused by Botrytis cinerea on apple, pear, and cut flowers (Hammer et al. 1993; Janisiewicz and Roitman 1988). It has been used to treat human infections by opportunistic fungi (Tawara et al. 1989) due to its very low toxicity to animals and humans. Like PCA, Prn has a relatively short half-life in the environment. A synthetic derivative of Prn with greater environmental stability was developed as the fungicide fludioxonil, which is now widely used against a variety of diseases (Brandhorst et al. 2019).

To our knowledge, our recombinants are the first in which the Prn operon has been stably introduced and expressed in the chromosome of a phenazine producer. The increase of inhibition in vitro of strains ZHW15 and ZHW25, compared with strain 2-79 and other strains of $P$. synxantha, $P$. orientalis, $P$. aridus, $P$. cerealis, and $P$. chlororaphis against $R$. solani AG-8, $R$. solani AG-2-1, $S$. sclerotiorum, F. pseudograminearum, and P. culmorum, clearly suggested the potential for improved biocontrol activity with the recombinants. The enhanced activity of strains ZHW15 and ZHW25 shown in the greenhouse studies was especially notable against Rhizoctonia root rot of wheat and root rot and damping-off of canola. This was not surprising because Prn is highly active against Rhizoctonia species. The key to the enhanced activity of the recombinants is that the introduced Prn operon is under control of the synthetic tac promoter and the antibiotic is constitutively produced, a trait which is needed on seeds and in the rhizosphere due to the short half-life of natural antibiotics in soil. It is notable that even with constitutive Prn production, which is energy demanding process of the metabolism of strain 2-79, the recombinants and 2-79 did not differ in ability to colonize the

TABLE 4. Colonization of the wheat rhizosphere by introduced wild-type strain 2-79 and recombinant strains ZHW15 and ZHW25

\begin{tabular}{llcc}
\hline & \multicolumn{3}{c}{$\begin{array}{c}\text { Log mean population density per gram of fresh root } \\
\text { weight }\end{array}$} \\
\cline { 2 - 4 } Cycle $^{y}$ & $2-79$ & ZHW15 & ZHW25 \\
\hline 1 & $7.20^{z}$ & 7.13 & 7.17 \\
2 & 6.87 & 7.44 & 7.00 \\
3 & 6.18 & 6.83 & 6.07 \\
\hline
\end{tabular}

y Each cycle of wheat (cultivar Penawawa) was grown for 3 weeks. At the end of cycle 1, soil and roots from replicate pots of the same treatment were combined, mixed, added back to the pots and sown to wheat again, beginning a new cycle. Wild-type strain $P$. synxantha 2-79 and recombinant strains ZHW15 and ZHW25 were introduced as seed treatments $\left(10^{5} \mathrm{CFU}\right.$ seed $^{-1}$ ) only in cycle 1 .

${ }^{z}$ Mean population densities of the three strains within a cycle were not significantly different $(P=0.05)$.

TABLE 3. Suppression of take-all of wheat and Rhizoctonia root rot of wheat and canola by Pseudomonas synxantha 2-79 and recombinant strains ZHW15 and ZHW25

\begin{tabular}{|c|c|c|c|c|}
\hline \multirow[b]{2}{*}{ Treatment ${ }^{\mathrm{w}}$} & \multirow{2}{*}{$\frac{\text { Take-all }}{\text { Disease rating (wheat) }}$} & \multicolumn{3}{|c|}{ Rhizoctonia root rot } \\
\hline & & Disease rating (wheat) & Damping-off (\%) (canola) & Shoot length $(\mathrm{mm})$ (canola) \\
\hline CK (+MC +pathogen) & $4.8 \mathrm{~A}^{\mathrm{y}}$ & $4.3 \mathrm{~A}$ & 94.4 & $\mathrm{ND}^{\mathrm{z}}$ \\
\hline ZHW15 & $2.8 \mathrm{D}$ & $1.6 \mathrm{C}$ & 15.1 & $60.0 \mathrm{~B}$ \\
\hline ZHW25 & $2.7 \mathrm{D}$ & $1.8 \mathrm{C}$ & 18.1 & $65.0 \mathrm{~A}$ \\
\hline CK (-pathogen -bacteria) & 0.1 & 0.1 & 0.0 & 75.0 \\
\hline
\end{tabular}

${ }^{\mathrm{w}} \mathrm{CK}=$ control, no bacteria; $\mathrm{CK}+\mathrm{MC}=$ seeds treated with methyl cellulose, no bacteria; bacteria were applied to the seed at a dose of $10^{7} \mathrm{CFU}$ seed ${ }^{-1}$; $\mathrm{CK}$ (-pathogen -bacteria) was not included in the analysis.

x Severity of root disease was rated on a 0 to 8 scale, where $0=$ no disease detected and $8=$ plant dead or nearly so. Damping-off and shoot length of canola was determined at 10 and 21 days after planting, respectively.

y Means in the same column followed by the same letter are not significantly different at $P=0.05$ according to either Fisher's protected least significant difference test (shoot length) or Kruskal-Wallis all-pairwise comparison test (disease rating).

${ }^{\mathrm{z}} \mathrm{ND}$, shoots were not measured because most or all the plants died. 
wheat rhizosphere. All three strains reached population sizes in the rhizosphere similar to what has previously been reported for strain 279 in the field (Yang et al. 2011). Similarly, Bankhead et al. (2016) reported that a recombinant of $P$. brassicacearum Q8r1-96 transformed with the PCA biosynthesis locus maintained its rhizosphere competence on wheat when introduced into the rhizosphere compared with the wild-type strain. However, when the recombinant and wild type were coinoculated, the wild-type out-competed the recombinant on wheat and barley but not on pea (Bankhead et al. 2016).

In conclusion, even though public sentiment remains opposed to the large-scale release of recombinant microorganisms, there is a need for renewed research to develop, field test, and stockpile recombinant biocontrol agents for future use. The potential total loss of a crop to a devastating disease, lacking conventional control measures, or the benefit of greatly reducing pesticide use inevitably will lead to the adoption of technologies that previously were off the table.

\section{LITERATURE CITED}

Arima, K., Imanaka, I., Kousaka, M., Fukuta, A., and Tamura, G. 1964. Pyrrolnitrin, a new antibiotic substance produced by Pseudomonas. Agric. Biol. Chem. 28:575-576.

Attanayake, R. N., Carter, P. A., Jiang, D., del Río-Mendoza, L., and Chen, W. 2013. Sclerotinia sclerotiorum populations infecting canola from China and the United States are genetically and phenotypically distinct. Phytopathology 103:750-761.

Bankhead, S. B., Thomashow, L. S., and Weller, D. M. 2016. Rhizosphere competence of wild-type and genetically-engineered Pseudomonas brassicacearum is affected by the crop species. Phytopathology 106:554-561.

Brandhorst, T. T., Kean, I. R. L., Lawry, S. M., Wiesner, D. L., and Klein, B. S. 2019. Phenylpyrrole fungicides act on triosephosphate isomerase to induce methylglyoxal stress and alter hybrid histidine kinase activity. Sci. Rep. 9:5047.

Chernin, L., Brandis, A., Ismailov, Z., and Chet, I. 1996. Pyrrolnitrin production by an Enterobacter agglomerans strain with broad-spectrum of antagonistic activity towards fungal and bacterial phytopathogens. Curr. Microbiol. 32:208-212.

Cook, R. J. 2003. Take-all of wheat. Physiol. Mol. Plant Pathol. 62:73-86.

Cook, R. J., Weller, D. M., Youssef El-Banna, A., Vakoch, D., and Zhang, H. 2002. Yield responses of direct-seeded wheat to rhizobacteria and fungicide seed treatments. Plant Dis. 86:780-784.

de Lorenzo, V., and Timmis, K. N. 1994. Analysis and construction of stable phenotypes in gram-negative bacteria with Tn5- and Tn10-derived minitransposons. Methods Enzymol. 235:386-405.

Dekkers, L. C., Mulders, I. H. M., Phoelich, C. C., Chin-A-Woeng, T. F. C., Wijfjes, A. H. M., and Lugtenberg, B. J. J. 2000. The sss colonization gene of the tomatoFusarium oxysporum f. sp. radicis-lycopersici biocontrol strain Pseudomonas fluorescens WCS365 can improve root colonization of other wild-type Pseudomonas spp. bacteria. Mol. Plant-Microbe Interact. 13:1177-1183.

del Río, L. E., Bradley, C. A., Henson, R. A., Endres, G. J., Hanson, B. K., McKay, K., Halvorson, M., Porter, P. M., Le Gare, D. G., and Lamey, H. A. 2007. Impact of Sclerotinia stem rot on yield of canola. Plant Dis. 91:191-194.

Delany, I. R., Walsh, U. F., Ross, I., Fenton, A. M., Corkery, D. M., and O'Gara, F. 2001. Enhancing the biocontrol efficacy of Pseudomonas fluorescens $\mathrm{F} 113$ by altering the regulation and production of 2,4-diacetylphloroglucinol. Plant Soil 232:195-205.

Dunne, C., Moënne-Loccoz, Y., de Bruijn, F. J., and O'Gara, F. 2000. Overproduction of an inducible extracellular serine protease improves biological control of Pythium ultimum by Stenotrophomonas maltophilia strain W81. Microbiology 146:2069-2078.

El-Banna, N., and Winkelmann, G. 1988. Pyrrolnitrin from Burkholderia cepacia: Antibiotic activity against fungi and novel activities against streptomycetes. J. Appl. Microbiol. 85:69-78.

Fenton, A. M., Stephens, P. M. J., Crowley, J., O'Callaghan, M., and O'Gara, F. 1992. Exploitation of genes(s) involved in 2,4-diacetylphloroglucinol biosynthesis to confer new biocontrol capability to a Pseudomonas strain. Appl. Environ. Microbiol. 58:3873-3878.

Fernando, W. G. D., Nakkeeran, S., Zhang, Y., and Savchuk, S. 2007. Biological control of Sclerotinia sclerotiorum (Lib.) de Bary by Pseudomonas and Bacillus species on canola petals. Crop Prot. 26:100-107.

Fu, T. D. 1995. Hybrid Breeding and Application. Hubei Science and Technology Press, Wuhan.

Haas, D., and Défago, G. 2005. Biological control of soil-borne pathogens by fluorescent pseudomonads. Nat. Rev. Microbiol. 3:307-319.

Hammer, P. E., Burd, W., Hill, D. S., Ligon, J. M., and Van Pee, K.-H. 1999. Conservation of the pyrrolnitrin biosynthetic gene cluster among six pyrrolnitrin-producing strains. FEMS Microbiol. Lett. 180:39-44.
Hammer, P. E., Evensen, K. B., and Janisiewicz, W. J. 1993. Post harvest control of Botrytis cinerea on cut rose flowers with pyrrolnitrin. Plant Dis. 77:283-286

Hill, D. S., Stein, J. I., Torkewitz, N. R., Morse, A. M., Howell, C. R., Pachlatko, J. P., Becker, J. O., and Ligon, J. M. 1994. Cloning of genes involved in the synthesis of pyrrolnitrin from Pseudomonas fluorescens and role of pyrrolnitrin synthesis in biological control of plant disease. Appl. Environ. Microbiol. 60:78-85.

House, B. L., Mortimer, M. W., and Kahn, M. L. 2004. New recombination methods for Sinorhizobium meliloti genetics. Appl. Environ. Microbiol. 70: 2806-2815.

Howell, C. R., and Stipanovic, R. D. 1979. Control of Rhizoctonia solani on cotton seedlings with Pseudomonas fluorescens and with an antibiotic produced by the bacterium. Phytopathology 69:480-482.

Hu, X., Roberts, D. P., Jiang, M., and Zhang, Y. 2005. Decreased incidence of disease caused by Sclerotinia sclerotiorum and improved plant vigor of oilseed rape with Bacillus subtilis Tu-100. Appl. Microbiol. Biotechnol. 68:802-807.

Huang, Z., Bonsall, R. F., Mavrodi, D. V., Weller, D. M., and Thomashow, L. S. 2004. Transformation of Pseudomonas fluorescens with genes for biosynthesis of phenazine-1-carboxylic acid improves biocontrol of Rhizoctonia root rot and in situ antibiotic production. FEMS Microbiol. Ecol. 49:243-251.

Huber, D. M., and Christmas, E. P. 1992. Rhizoctonia crown rot of canola in Indiana. Plant Dis. 76:1251-1253.

Jaaffar, A. K. M., Paulitz, T. C., Schroeder, K. L., Thomashow, L. S., and Weller, D. M. 2016. Molecular characterization, morphological characteristics, virulence and geographic distribution of Rhizoctonia spp. in Washington State, USA. Phytopathology 106:459-473.

Jaaffar, A. K. M., Parejko, J., Paulitz, T. C., Weller, D. M., and Thomashow, L. S. 2017. Sensitivity of Rhizoctonia isolates to phenazine-1-carboxylic acid and biological control by phenazine-producing Pseudomonas spp. Phytopathology 107:692-703.

Janisiewicz, W. J., and Roitman, J. 1988. Biological control of blue mold and grey mold on apple and pear with Pseudomonas cepacia. Phytopathology 78:1697-1700.

Jousset, A., Schuldes, J., Keel, C., Maurhofer, M., Daniel, D., Scheu, S., and Thuermer, A. 2014. Full-genome sequence of the plant growth-promoting bacterium Pseudomonas protegens CHA0. Genome Announc. 2:e00322-e14.

Kaminski, D. A., and Verma, P. R. 1985. Cultural characteristics, virulence and in vitro temperature effect on mycelial growth of Rhizoctonia solani from rapeseed. Can. J. Plant Pathol. 7:256-261.

Kataria, H. R., and Verma, P. R. 1992. Rhizoctonia solani damping-off and root rot in oilseed rape and canola. Crop Prot. 11:8-13.

Khan, S. R., Mavrodi, D. V., Jog, G. J., Suga, H., Thomashow, L. S., and Farrand, S. K. 2005. Activation of the phz operon of Pseudomonas fluorescens 2-79 requires the LuxR homolog PhzR, N-(3-OH-hexanoyl)L-homoserine lactone produced by PhzI, and a cis-acting phz-box. J. Bacteriol. 187:6517-6527.

Khangura, R. K., Barbetti, M. J., and Sweetingham, M. W. 1999. Characterization and pathogenicity of Rhizoctonia species on canola. Plant Dis. 83: 714-721.

Klein-Gebbinck, H. W., and Woods, D. L. 2002. Yield loss assessment in canola: effects of brown girdling root rot and maggot damage on single plant yield. Plant Dis. 86:1005-1010.

Koch, B., Jensen, L. E., and Nybroe, O. 2001. A panel of Tn7-based vectors for insertion of the $g f p$ marker gene or for delivery of cloned DNA into gram-negative bacteria at a neutral chromosomal site. J. Microbiol. Methods 45:187-195.

Kwak, Y. S., Bakker, P. A. H. M., Glandorf, D. C. M., Rice, J. T., Paulitz, T. C., and Weller, D. M. 2009. Diversity, virulence, and 2,4-diacetylphloroglucinol sensitivity of Gaeumannomyces graminis var. tritici isolates from Washington State. Phytopathology 99:472-479.

Leclère, V., Béchet, M., Adam, A., Guez, J.-S., Wathelet, B., Ongena, M., Thonart, P., Gancel, F., Chollet-Imbert, M., and Jacques, P. 2005. Mycosubtilin overproduction by Bacillus subtilis BBG100 enhances the organism's antagonistic and biocontrol activities. Appl. Environ. Microbiol. 71:4577-4584.

LeTourneau, M. K., Marshall, M. J., Cliff, J. B., Bonsall, R. F., Dohnalkova, A. C., Mavrodi, D. V., Devi, S. I., Mavrodi, O. V., Harsh, J. B., Weller, D. M., and Thomashow, L. S. 2018. Phenazine-1-carboxylic acid and soil moisture influence biofilm development and turnover of rhizobacterial biomass on wheat root surfaces. Environ. Microbiol. 20:2178-2194.

LeTourneau, M. K., Marshall, M. J., Grant, M., Freeze, P. M., Strawn, D. G., Lai, B., Dohnalkova, A. C., Harsh, J. B., Weller, D. M., and Thomashow, L. S. 2019. Phenazine-1-carboxylic acid-producing bacteria enhance the reactivity of iron minerals in dryland and irrigated wheat rhizospheres. Environ. Sci. Technol. 53:14273-14284.

Loper, J. E., Hassan, K. A., Mavrodi, D. V., Davis, E. W., Lim, C. K., Shaffer, B. T., Elbourne, L. D., Stockwell, V. O., Hartney, S. L., Breakwell, K., Henkels, M. D., Tetu, S. G., Rangel, L. I., Kidarsa, T. A., Wilson, N. L., van Mortel, J., Song, C., Blumhagen, R., Radune, D., Hostetler, J. B., 
Brinkac, L. M., Durkin, S. A., Kluepfel, D. A., Wechter, P. W., Anderson, A. J., Kim, Y. C., Pierson, L. S., Pierson, E. A., Lindow, S. E., Raaijmakers, J. M., Weller, D. M., Thomashow, L. S., Allen, A. E., and Paulsen, I. T. 2012. Comparative genomics of plant-associated Pseudomonas spp: Insights into diversity and inheritance of traits involved in multitrophic interactions. PLoS Genet. 8:e1002784.

Loper, J. E., Kobayashi, D. Y., and Paulsen, I. T. 2007. The genomic sequence of Pseudomonas fluorescens Pf-5: Insights into biological control. Phytopathology 97:233-238.

MacNish, G. C., and Neate, S. M. 1996. Rhizoctonia bare patch: An Australian perspective. Plant Dis. 80:965-971.

Maurhofer, M., Reimmann, C., Schmidli-Sacherer, P., Heeb, S., Haas, D., and Défago, G. 1998. Salicylic acid biosynthetic genes expressed in Pseudomonas fluorescens strain P3 improve the induction of systemic resistance in tobacco against tobacco necrosis virus. Phytopathology 88:678-684.

Mavrodi, D. V., Mavrodi, O. V., Elbourne, L. D. H., Tetu, S., Bonsall, R. F., Parejko, J., Yang, M., Paulsen, I. T., Weller, D. M., and Thomashow, L. S. 2018. Long-term irrigation affects the dynamics and activity of the wheat rhizosphere microbiome. Front. Plant Sci. 9:345.

Mavrodi, D. V., Mavrodi, O. V., Parejko, J. A., Bonsall, R. F., Kwak, Y.-S., Paulitz, T. C., Thomashow, L. S., and Weller, D. M. 2012. Accumulation of the antibiotic phenazine-1-carboxylic acid in the rhizosphere of dryland cereals. Appl. Environ. Microbiol. 78:804-812.

Mazzola, M., Cook, R. J., Thomashow, L. S., Weller, D. M., and Pierson, L. S. 1992. Contribution of phenazine antibiotic biosynthesis to the ecological competence of fluorescent pseudomonads in soil habitats. Appl. Environ. Microbiol. 58:2616-2624.

Okubara, P. A., Schroeder, K. L., Abatzoglou, J. T., and Paulitz, T. C. 2014. Agroecological factors correlated to soil DNA concentrations of Rhizoctonia in dryland wheat production zones of Washington state, USA. Phytopathology 104:683-691.

Parejko, J. A., Mavrodi, D. M., Mavrodi, O. V., Weller, D. M., and Thomashow, L. S. 2013. Taxonomy and distribution of phenazine-1carboxylic acid-producing Pseudomonas spp. in the dryland agroecosystem of the Inland Pacific Northwest. Appl. Environ. Microbiol. 79:3887-3891.

Parejko, J. A., Mavrodi, D. V., Mavrodi, O. V., Weller, D. M., and Thomashow, L. S. 2012. Population structure of phenazine-1-carboxylic acid producing fluorescent Pseudomonas spp. from dryland cereal fields of central Washington State (USA). Microbiol. Ecol. 64:226-241.

Paulitz, T. C. 2006. Low input no-till cereal production in the Pacific Northwest of the US: The challenges of root diseases. Eur. J. Plant Pathol. 115:271-281.

Paulitz, T. C., Okubara, P. A., and Schillinger, W. F. 2006. First report of damping-off of canola caused by Rhizoctonia solani AG 2-1 in Washington State. Plant Dis. 90:829.

Paulitz, T. C., Schroeder, K. L., and Schillinger, W. F. 2010. Soilborne pathogens of cereals in an irrigated cropping system: Effects of tillage, residue management, and crop rotation. Plant Dis. 94:61-68.

Paulitz, T. C., Smiley, R., and Cook, R. J. 2002. Insights into the prevalence and management of soilborne cereal pathogens under direct seeding in the Pacific Northwest, U.S.A. Can. J. Plant Pathol. 24:416-428.

Paulsen, I. T., Press, C., Ravel, J., Kobayashi, D. Y., Myers, G. S. A., Mavrodi, D. V., DeBoy, R. T., Seshadri, R., Ren, Q., Madupu, R., Dodson, R. J., Durkin, A. S., Brinkac, L. M., Daugherty, S. C., Sullivan, S. A., Rosovitz, M. J., Gwinn, M. L., Zhou, L., Nelson, W. C., Weidman, J., Watkins, K., Tran, K., Khouri, H., Pierson, E. A., Pierson, L. S., III, Thomashow, L. S., and Loper, J. E. 2005. Complete genome sequence of the plant commensal Pseudomonas fluorescens Pf-5: Insights into the biological control of plant disease. Nat. Biotechnol. 23:873-878.

Péchy-Tarr, M., Bruck, D. J., Mauhofer, M., Fischer, E., Vogne, C., Henkels, M. D., Donahue, K. M., Grunder, J., Loper, J. E., and Keel, C. 2008. Molecular analysis of a novel gene cluster encoding an insect toxin in plant associated strains of Pseudomonas fluorescens. Environ. Microbiol. 10:2368-2386.

Pierson, E. A., and Weller, D. M. 1994. Use of mixtures of fluorescent pseudomonads to suppress take-all and improve the growth of wheat. Phytopathology 84:940-947.

Pierson, L. S., III, and Thomashow, L. S. 1992. Cloning and heterologous expression of the phenazine biosynthetic locus from Pseudomonas aureofaciens 30-84. Mol. Plant-Microbe Interact. 5:330-339.

Poole, G. J. 2010. Identification of quantitative trait loci (QTL) for resistance to Fusarium crown rot in wheat and a survey of Fusarium pseudograminearum and F. culmorum in the Pacific Northwest of the US. Ph.D. Dissert., Washington State University, Pullman.

Raaijmakers, J. M., Van der Sluis, L., Bakker, P. A. H. M., Schippers, B., Koster, M., and Weisbeek, P. J. 1995. Utilization of heterologous siderophores and rhizosphere competence of fluorescent Pseudomonas spp. Can. J. Microbiol. 41:126-135.

Ramette, A., Frapolli, M., Fischer-Le Saux, M., Gruffaz, C., Meyer, J. M., Defago, G., Sutra, L., and Moënne-Loccoz, Y. 2011. Pseudomonas protegens sp nov., widespread plant-protecting bacteria producing the biocontrol compounds 2,4diacetylphloroglucinol and pyoluteorin. Syst. Appl. Microbiol. 34:180-188.

Schillinger, W. F., and Paulitz, T. C. 2006. Reduction of Rhizoctonia bare patch in wheat and barley rotations. Plant Dis. 90:302-306.

Schlatter, D., Kinkel, L., Thomashow, L., Weller, D., and Paulitz, T. 2018. Disease suppressive soils: New insights from the soil microbiome. Phytopathology 107:1284-1297.

Schroeder, K. L., Okubara, P. A., Tambong, J. T., Lévesque, C. A., and Paulitz, T. C. 2006. Identification and quantification of pathogenic Pythium spp. from soils in eastern Washington using real-time polymerase chain reaction. Phytopathology 96:637-647.

Schroeder, K. L., and Paulitz, T. C. 2006. Root diseases of wheat and barley during the transition from conventional tillage to direct seeding. Plant Dis. 90:1247-1253.

Schroeder, K. L., and Paulitz, T. C. 2008. Effect of inoculum density and soil tillage on the development and severity of Rhizoctonia root rot. Phytopathology 98:304-314.

Smiley, R. W., Gourlie, J. A., Easley, S. A., Patterson, L.-M., and Whittaker, R. G. 2005. Crop damage estimates for crown rot of wheat and barley in the Pacific Northwest. Plant Dis. 89:595-604.

Tawara, S., Matsumoto, S., Hirose, T., Matsumoto, Y., Nakamoto, S., Mitsuno, M., and Kamimura, T. 1989. In vitro antifungal synergism between pyrrolnitrin and clotrimazole. J. Med. Mycol. 30:202-210.

Thomashow, L. S., and Weller, D. M. 1988. Role of a phenazine antibiotic from Pseudomonas fluorescens in biological control of Gaeumannomyces graminis var. tritici. J. Bact. 170:3499-3508.

Thomashow, L. S., Weller, D. M., Bonsall, R. F., and Pierson, L. S., III. 1990. Production of the antibiotic phenazine-1-carboxylic acid by fluorescent Pseudomonas species in the rhizosphere of wheat. Appl. Environ. Microbiol. 56:908-912.

Timms-Wilson, T. M., Ellis, R. J., Renwick, A., Rhodes, D. J., Mavrodi, D. V., Weller, D. M., Thomashow, L. S., and Bailey, M. J. 2000. Chromosomal insertion of the phenazine-1-carboxylic acid biosynthetic pathway enhances efficacy of damping-off disease control by Pseudomonas fluorescens. Mol. Plant-Microbe Interact. 13:1293-1300.

Voisard, C., Keel, C., Haas, D., and Défago, G. 1989. Cyanide production by Pseudomonas fluorescens helps suppress black root rot of tobacco under gnotobiotic conditions. EMBO J. 8:351-358.

Wang, X., Mavrodi, D. V., Ke, L., Mavrodi, O., Yang, M., Thomashow, L. S., Zheng, N., Weller, D. M., and Zhang, J. 2015. Biocontrol and plant growthpromoting activity of rhizobacteria from Chinese fields with contaminated soils. Microb. Biotechnol. 8:404-418.

Weller, D. M. 1983. Colonization of wheat roots by a fluorescent pseudomonad suppressive to take-all. Phytopathology 73:1548-1553.

Weller, D. M. 1984. Distribution of a take-all suppressive strain of Pseudomonas fluorescens on seminal roots of winter wheat. Appl. Environ. Microbiol. 48:897-899.

Weller, D. M. 2007. Pseudomonas biocontrol agents of soilborne pathogens: Looking back over 30 years. Phytopathology 97:250-256.

Weller, D. M., and Cook, R. J. 1983. Suppression of take all of wheat by seed treatments with fluorescent pseudomonads. Phytopathology 73:463-469.

Weller, D. M., Cook, R. J., MacNish, G., Bassett, E. N., Powelson, R. L., and Petersen, R. R. 1986. Rhizoctonia root rot of small grains favored by reduced tillage in the Pacific Northwest. Plant Dis. 70:70-73.

Weller, D. M., Raaijmakers, J. M., McSpadden Gardener, B. B., and Thomashow, L. S. 2002. Microbial populations responsible for specific suppressiveness to plant pathogens. Annu. Rev. Phytopathol. 40:309-348.

Weller, D. M., and Thomashow, L. S. 2015. Phytosanitation and the development of transgenic biocontrol agents. Pages 35-43 in: OECD Biosafety and the Environmental Uses of Micro-Organisms, Conference Proceedings, OECD Publishing, Paris.

Weller, D. M., van Pelt, J. A., Pieterse, C. M. J., and Bakker, P. A. H. M. 2015. Disease suppressive soils induce systemic resistance in Arabidopsis thaliana against Pseudomonas syringae pv. tomato. Phytopathology 105(Suppl. 4):S4.147.

Xu, L., Xiang, M., White, D., and Chen, W. 2015. pH dependency of sclerotial development and pathogenicity revealed by using genetically defined oxalateminus mutants of Sclerotinia sclerotiorum. Environ. Microbiol. 17:2896-2909.

Yang, M.-M., Mavrodi, D. V., Mavrodi, O. V., Bonsall, R. F., Parejko, J. A., Paulitz, T. C., Thomashow, L. S., Yang, H.-T., Weller, D. M., and Guo, J.-H. 2011. Biological control of take-all by fluorescent Pseudomonas spp. from Chinese wheat fields. Phytopathology 101:1481-1491.

Yang, M.-M., Wen, S.-S., Mavrodi, D. V., Mavrodi, O. V., Thomashow, L. S., Guo, J.-H., and Weller, D. M. 2014. Biological control of wheat root diseases by the CLP-producing strain Pseudomonas fluorescens HC1-07. Phytopathology 104:248-256.

Zhao, X., Chen, Z., Yu, L., Hu, D., and Song, B. 2018. Investigating the antifungal activity and mechanism of a microbial pesticide Shenqinmycin against Phoma sp. Pestic. Biochem. Physiol. 147:46-50. 